\title{
The effect of disinfectants on fungal diseases of potato and vegetables
}

\author{
HILKKa KoPONEN, HanNa AVIKAINEN and RISTO TAHVONEN
}

Koponen, H., Avikainen, H. \& Tahyonen, R. 1993. The effect of disinfectants on fungal diseases of potato and vegetables. Agric. Sci. Finl. 2: 169-177. (Dept. PI. Biol., P.O.Box 28, FIN-00014 University of Helsinki, Finland and Agric. Res. Centre of Finland, Inst. Pl. Prot., FIN-31600 Jokioinen, Finland.)

Treatments of one and ten minutes were too short for all disinfectants against fungi in peat and plant debris. The best effect was achieved with a treatment of $90 \mathrm{~min}$. Sodium hypochlorite $(\mathrm{NaOCl})$ was the most effective and Korsolin and Virkon $\mathrm{S}$ were the least effective in the control of Fusarium culmorum and F. oxysporum. Virkon $\mathrm{S}(2 \%)$ was the most effective against Mycocentrospora acerina and Phoma foveata.

Soaking for $15 \mathrm{~min}$ and $60 \mathrm{~min}$ in a disinfection suspension eradicated Botrytis cinerea and $P$. foveata totally from the contaminated plastic pots. Fusarium spp. were the most difficult fungi to disinfect and these were best controlled with formaline, Iobac P, Menno-Ter-forte and sodium hypochlorite.

Iobac P, formaline, Menno-Ter-forte, Taloset and Virkon S were the most effective disinfectants against club rot (Plasmodiophora brassicae).Washing under running water was not sufficient to eradicate club rot. Against Rhizoctonia -induced dampingoff of cauliflower the most effective disinfectants were formaline and Virkon $\mathrm{S}$.

Key words: Botrytis cinerea, disinfection, Fusarium culmorum, F. oxysporum, Mycocentrospora acerina, Phoma foveata, Plasmodiophora brassicae, Rhizoctonia solani

\section{Introduction}

Many plant diseases, which cause a decrease of yield and yield quality, survive on plant debris, growth substrates, mull debris, and greenhouse and storage structures for long periods. Therefore it is essential to use disinfectants to prevent the spread of diseases by those routes. Disinfection of soil substrate is not at present topical, because new peat or other currently used substrates are free of diseases.

Grey mould (Botrytis cinerea) is a common disease in vegetables and ornamental plants grown in greenhouses as well as in vegetable storages (HeInZE 1974, DenNIS 1983). Fusarium spp. are also commonly encountered in vegetables. They cause Fusarium rot (Fusarium avenaceum and $F$. solani var. coeruleum) of potato (SEPPÄNEN 1983), wilt disease (Fusarium oxysporum) of tomato and cucumber, as well as damping-off and foot rot $(F$. culmorum, F. avenaceum). Phoma spp. cause damping-off, stem rot and various leaf spot diseases in greenhouses as well as Phoma rot (Phoma foveata) of potato. Club rot (Plasmodiophora brassicae) and damping-off (Rhizoctonia solani) are a major problem in cabbage cultivation, as soil-borne diseases also in seedling cultivation (HEINZE 1974). Liquorice rot (Mycocentrospora acerina) has become a common disease of carrots in storage (DENNIS 1983).

In order to prevent the spread of pathogens on a farm and from one farm to another, greenhouses, 
seed storages, machines and tools must be disinfected. There are several disinfectants on the market, but little is known about their applicability in plant production against important and common diseases. In 1988-1990, studies were conducted to determine the effect of disinfectants against fungal diseases of vegetables and potato.

\section{Material and methods}

The effect of nine disinfectants (Table 1) in the control of potato and vegetable diseases was tested at the Institute of Plant Protection of the Agricultural Research Centre. Mostly the concentrations recommended by the manufacturers were used in the trials. The disinfectants were diluted in water.

The test fungi used were Botrytis cinerea, Fusarium culmorum, $F$. oxysporum, Mycocentrospora acerina, Phoma foveata, Plasmodiophora brassicae and Rhizoctonia solani. The names of the fungi are mainly according to DOMSCH et al. (1980). The fungal isolates included in the study were obtained from the collections of the Institute of Plant Protection of the Agricultural Research Centre. The fungi were cultivated on different media depending on the fungus (Table 2). The formulas for culture media of fungi are presented in BоOTH (1971).

The results were tested using the analysis of variance, and significances with Tukey's test.

\section{The effect of disinfectants on the pathogens in peat and plant debris}

The effect of disinfectants on the pathogens in peat and plant debris was investigated in laboratory trials. The inoculated peat was obtained by mixing one Petri dish culture of fungus ( $F$. culmorum and $F$. oxysporum) and $100 \mathrm{ml}$ of water in one litre of peat. The recommended concentrations $(\mathrm{N})$ of disinfectants and a lower concentration $\left(10^{-1} \mathrm{~N}\right)$ were used. Inoculated peat, 1.0 and $0.1 \mathrm{~g}$, was mixed in 11 of disinfection suspension. The preparation was allowed to act for 1,10 and $100 \mathrm{~min}$. Thereafter the suspension was filtered. The filter paper was
Table 1. The disinfectants, their active ingredients and concentrations recommended by the manufacturers.

\begin{tabular}{|c|c|c|}
\hline Disinfectant & Active ingredient, $\%$ & $\begin{array}{c}\text { Recommended } \\
\text { concentration, } \\
\%\end{array}$ \\
\hline Formaline & Formaldehyde, 37 & 5.0 \\
\hline Iobac P & Iodine, 1.8 & \\
\hline Ipasept & $\begin{array}{l}\text { Quaternary ammo- } \\
\text { nium compounds, } 2.8\end{array}$ & 2.0 \\
\hline Korsolin & Glutaraldehyde, 10 & \\
\hline Menno-Ter-forte & $\begin{array}{l}\text { Quaternary ammo- } \\
\text { nium compounds, } \\
32.5\end{array}$ & 1.0 \\
\hline Sanisept & $\begin{array}{l}\text { Quaternary ammo- } \\
\text { nium compounds, } 2.5\end{array}$ & 2.0 \\
\hline $\begin{array}{l}\text { Sodium hypochlorite } \\
(\mathrm{NaOCl})\end{array}$ & Active chlorine, 10 & \\
\hline Taloset & $\begin{array}{l}\text { Quaternary ammo- } \\
\text { nium compounds, } 3.5\end{array}$ & 2.0 \\
\hline Virkon S & $\begin{array}{l}\text { Potassium peroxysul- } \\
\text { phate, } 60\end{array}$ & 1.0 \\
\hline
\end{tabular}

Table 2. The growth media used in the fungal cultures.

\begin{tabular}{|c|c|}
\hline Fungus & Growth medium \\
\hline Botrytis cinerea & $\begin{array}{l}\text { Corn meal agar (Difco) }+100 \mathrm{ppm} \\
\text { streptomycin sulphate }\end{array}$ \\
\hline Fusarium culmorum & Nash and Snyder PCNB medium \\
\hline F. oxysporum & Nash and Snyder PCNB medium \\
\hline $\begin{array}{l}\text { Mycocentrospora } \\
\text { acerina }\end{array}$ & $\begin{array}{l}\text { Corn meal agar (Difco) }+100 \mathrm{ppm} \\
\text { streptomycin sulphate }\end{array}$ \\
\hline \multirow[t]{2}{*}{ Phoma foveata } & Malt extract agar (Difco) \\
\hline & $\begin{array}{l}\text { Corn meal agar (Difco) }+100 \mathrm{ppm} \\
\text { streptomycin sulphate }\end{array}$ \\
\hline Rhizoctonia solani & Rhizoctonia agar (Ko and HoRA 1971) \\
\hline
\end{tabular}

washed with water $(50 \mathrm{ml})$ and pieces of the filter paper were placed onto different agar plates depending on the test fungus (Table 2) (4 pieces/plate) to determine the viability of the fungi. The trial was made with three replicates.

The effect of disinfectants on fungi was tested on polyethene surfaces. The inner surfaces of the plastic pots were scratched with sandpaper and contaminated with fungus-peat inoculate. The inoculate used was obtained by mixing one plate of fungus ( $F$. culmorum, F.oxysporum and $R$. solani) and 
$100 \mathrm{ml}$ sterile water in one litre of peat, or by mixing five crushed pieces ( $4 \mathrm{~cm}$ long) of infected (B.cinerea, $M$. acerina and $P$. foveata) plant and $100 \mathrm{ml}$ of sterile water in one litre of peat. The contaminated pots were allowed to dry for 1-2 days. Pieces $(4 \times 6 \mathrm{~cm})$ cut from the plastic pots were soaked for 15 and $60 \mathrm{~min}$ in the disinfection solution $(100 \mathrm{ml})$. They were rinsed with water and cut into pieces of $0.5 \mathrm{~cm}$ onto different agar plates as above. The plates were evaluated after one and three weeks. The results were calculated as efficiency percentages, i.e. the proportion of healthy pieces on agar plates of all pieces.

The effect of disinfectants on liquorice rot of carrot ( $M$. acerina) and $P$. foveata of potato was investigated in a storage environment by inoculating carrots and potatoes with disinfected peat containing the respective fungus. One decilitre (30 g) of peat inoculated with Mycocentrospora or Phoma and 21 of disinfection suspension were mixed. After $30 \mathrm{~min}$ (trial 1) or $60 \mathrm{~min}$ (trial 2) the peat was filtered and washed with water. The potatoes and carrots were washed and surface sterilized with $0.1 \% \mathrm{NaOCl}$ solution for $2 \mathrm{~min}$ and thereafter washed with distilled water. Four holes $(1 \mathrm{~cm}$ in diameter and $0.5 \mathrm{~cm}$ deep) were made in the potatoes and three holes in the carrots using a cork borer. The holes were filled with inoculated and disinfected peat.

The carrots were stored at $+5^{\circ} \mathrm{C}$ and the potatoes at $+10-+12^{\circ} \mathrm{C}$ for $4-6$ weeks in the dark. Clean peat as well as water treated infected peat were used as controls. The trial was made with four replicates, ten treatments per replicate. The trial was repeated twice. The spread of the disease in the holes was evaluated in millimetres. The efficiency percentage of the disinfectants was calculated by comparing the treatments with the healthy controls and water treatments.

\section{The effect of disinfectants on club rot (Plasmodiophora brassicae)}

The club rot trials were carried out in the greenhouse. The containers (Vefi) were contaminated with Plasmodiophora brassicae infested soil (1.0 1 soil/1 1 water). The soil was taken from a club rot infected rape field. The containers were allowed to dry for one day before disinfection treatments.

The treatments were: $1=$ control, no washing, no disinfection; 2=washing under running water; $3=$ washing under running water, disinfection for 60 min.

After disinfection the containers were rinsed with water. On the next day about 130 rape seeds cv. 'Kova' were sown in fertilized peat (peat compound fertilizer $150 \mathrm{~g}$ and Dolomite lime $800 \mathrm{~g} / 100$ l peat). Additional light of 6000 lux was given to the plants. The trial was made with three replicates. The seedlings were grown for about 6 weeks, until the end of flowering. The severity of the infection was determined as the proportion of infected seedlings of all seedlings. The efficiency percentage was determined by comparing the effect of the preparation with the treatment of no washing.

\section{The effect of disinfectants on damping-off (Rhizoctonia solani)}

The inoculated peat used in the trials was obtained by mixing one Petri dish culture of Rhizoctonia solani and $100 \mathrm{ml}$ of water in one litre of peat. One decilitre of inoculated peat + one decilitre of fresh peat and two litres of disinfection suspension were mixed. The disinfectant was allowed to affect for $60 \mathrm{~min}$. The suspension was filtered and the peat was rinsed with water twice. The fresh peat was used as a growth medium in plastic pots (1 1). A layer of $1 \mathrm{~cm}$ of disinfected inoculated peat was placed on fresh peat. Thirty-six seeds of cauliflower cv. 'Tanskalainen suuri' were sown in the fresh peat and covered with a $0.5 \mathrm{~cm}$ layer of fresh peat. The number of replicates were five. The trial was repeated three times. The substrate, temperature and light conditions were as above in the club rot trial. The conditions of seedlings were checked 20 days after sowing. The results were calculated as the proportion of healthy seedlings of all seedlings. 
Table 3. The effect of concentration and disinfection time on Fusarium culmorum in peat debris. Disinfectants and concentrations (N): 1 = formaline $(5 \%), 2=\operatorname{Iobac} \mathrm{P}(3 \%), 3=\operatorname{Ipasept}(2 \%), 4=$ Korsolin $(1 \%), 5=$ Menno-Ter-forte $(1 \%), 6=\mathrm{NaOCl}$ $(10 \%), 7=$ Virkon S $(2 \%)$.

\begin{tabular}{|c|c|c|c|c|c|c|c|c|c|}
\hline \multirow{2}{*}{$\begin{array}{l}\text { Concen- } \\
\text { tration of } \\
\text { disinfectant }\end{array}$} & \multirow{2}{*}{$\begin{array}{c}\text { Peat } \\
\mathrm{g} / 1 \mathrm{l} \\
\text { disinfectant }\end{array}$} & \multicolumn{8}{|c|}{ Disinfectant } \\
\hline & & $\begin{array}{c}\text { Time } \\
\text { min }\end{array}$ & 1 & 2 & 3 & 4 & 5 & 6 & 7 \\
\hline & & \multicolumn{8}{|c|}{ Efficiency \% } \\
\hline \multirow{6}{*}{$\begin{array}{l}\text { Concen- } \\
\text { tration }(\mathrm{N})\end{array}$} & 1 & 1 & 0 & 50 & 93 & 5 & 95 & 93 & 0 \\
\hline & & 10 & 8 & 83 & 93 & 18 & 98 & 100 & 68 \\
\hline & & 100 & 93 & 93 & 93 & 5 & 95 & 100 & 100 \\
\hline & 0.1 & 1 & 0 & 80 & 95 & 8 & 100 & 93 & 0 \\
\hline & & 10 & 93 & 88 & 93 & 45 & 100 & 100 & 0 \\
\hline & & 100 & 93 & 95 & 95 & 25 & 100 & 100 & 75 \\
\hline \multirow[t]{6}{*}{$10^{-1} \mathrm{~N}$} & 1 & 1 & - & 8 & 20 & 0 & 93 & 38 & 0 \\
\hline & & 10 & & 0 & 13 & 0 & 93 & 75 & 0 \\
\hline & & 100 & - & 45 & 33 & 0 & 93 & 88 & 18 \\
\hline & 0.1 & 1 & & 33 & 83 & 0 & 95 & 0 & 0 \\
\hline & & 10 & - & 68 & 88 & 0 & 98 & 18 & 0 \\
\hline & & 100 & - & 95 & 93 & 0 & 98 & 83 & 8 \\
\hline
\end{tabular}

Table 4. The effect of concentration and disinfection time on Fusarium oxysporum in peat debris. Disinfectants and concentrations $(\mathrm{N}): 1=$ formaline $(5 \%), 2=\operatorname{Iobac} P(3 \%), 3=\operatorname{Ipasept}(2 \%), 4=$ Korsolin $(1 \%), 5=$ Menno-Ter-forte $(1 \%)$, $6=\mathrm{NaOCl}(10 \%), 7=\operatorname{Virkon} \mathrm{S}(2 \%)$.

\begin{tabular}{|c|c|c|c|c|c|c|c|c|c|}
\hline \multirow{2}{*}{$\begin{array}{l}\text { Concen- } \\
\text { tration of } \\
\text { disinfectant }\end{array}$} & \multirow{2}{*}{$\begin{array}{c}\text { Peat } \\
\mathrm{g} / 11 \\
\text { disinfectant }\end{array}$} & \multicolumn{8}{|c|}{ Disinfectant } \\
\hline & & $\begin{array}{c}\text { Time } \\
\text { min }\end{array}$ & 1 & 2 & 3 & 4 & 5 & 6 & 7 \\
\hline
\end{tabular}

\begin{tabular}{|c|c|c|c|c|c|c|c|c|c|}
\hline \multirow{6}{*}{$\begin{array}{l}\text { Concen- } \\
\text { tration } \\
\text { (N) }\end{array}$} & 1 & 1 & 0 & 8 & 33 & 50 & 75 & 33 & 25 \\
\hline & & 10 & 17 & 30 & 55 & 50 & 93 & 75 & 0 \\
\hline & & 100 & 83 & 93 & 83 & 88 & 88 & 100 & 68 \\
\hline & 0.1 & 1 & 0 & 70 & 80 & 0 & 95 & 93 & 0 \\
\hline & & 10 & 100 & 83 & 88 & 50 & 100 & 100 & 8 \\
\hline & & 100 & 100 & 93 & 93 & 50 & 100 & 100 & 100 \\
\hline \multirow[t]{6}{*}{$10^{-1} \mathrm{~N}$} & 1 & 1 & - & 0 & 0 & 8 & 0 & 8 & 0 \\
\hline & & 10 & - & 5 & 0 & 8 & 8 & 0 & 0 \\
\hline & & 100 & - & 55 & 0 & 50 & 45 & 0 & 0 \\
\hline & 0.1 & 1 & - & 20 & 5 & 0 & 70 & 0 & 0 \\
\hline & & 10 & - & 85 & 5 & 0 & 80 & 0 & 0 \\
\hline & & 100 & - & 100 & 50 & 25 & 95 & 8 & 25 \\
\hline
\end{tabular}

\section{Results}

The effect of disinfectants on pathogens in peat and plant debris

$\mathrm{NaOCl}$ was the most effective in the control of Fusarium culmorum when peat $(1.0-0.1 \mathrm{~g})$ was mixed in disinfectant. Also Menno-Ter-forte performed well. Korsolin was the weakest preparation (Table 3). $\mathrm{NaOCl}$ was effective also against $F$. oxysporum. The $100 \mathrm{~min}$ treatment time with Menno-Ter-forte, formaline and Virkon S was sufficient to disinfect the smallest amount of peat $(0.1$ g). Korsolin was the weakest preparation (Table 
Table 5. The effect of disinfection against fungi on the surface of plastic pots contaminated with fungus-peat mixture.

\begin{tabular}{|c|c|c|c|c|c|}
\hline Treatment & $\begin{array}{l}\text { Botrytis } \\
\text { cinerea }\end{array}$ & $\begin{array}{l}\text { Fusarium } \\
\text { culmorum }\end{array}$ & $\begin{array}{c}\text { Fusarium } \\
\text { oxysporum }\end{array}$ & $\begin{array}{l}\text { Phoma } \\
\text { foveata }\end{array}$ & $\begin{array}{c}\text { Rhizoctonia } \\
\text { solani }\end{array}$ \\
\hline & \multicolumn{5}{|c|}{ Minimum time min / efficiency $\%$} \\
\hline Water & $60 / 83$ & $60 / 0$ & $60 / 25$ & $60 / 8$ & $60 / 42$ \\
\hline Formaline & $15 / 100$ & $60 / 100$ & $15 / 100$ & $15 / 100$ & $15 / 100$ \\
\hline Iobac P & $15 / 100$ & $15 / 100$ & $60 / 100$ & $15 / 100$ & $15 / 100$ \\
\hline Ipasept & $15 / 100$ & $60 / 75$ & $60 / 100$ & $15 / 100$ & $60 / 100$ \\
\hline Korsolin & $60 / 100$ & $60 / 17$ & $60 / 92$ & $60 / 100$ & $60 / 58$ \\
\hline Menno-Ter-forte & $15 / 100$ & $15 / 100$ & $15 / 100$ & $15 / 100$ & $15 / 100$ \\
\hline $\mathrm{NaOCl}$ & $15 / 100$ & $15 / 100$ & $60 / 100$ & $15 / 100$ & $15 / 100$ \\
\hline Sanisept & $15 / 100$ & $60 / 50$ & $60 / 92$ & $60 / 100$ & $60 / 100$ \\
\hline Taloset & $15 / 100$ & $60 / 100$ & - & - & $15 / 100$ \\
\hline Virkon S, $2 \%$ & $15 / 100$ & $60 / 100$ & $60 / 92$ & $15 / 100$ & $60 / 75$ \\
\hline
\end{tabular}

Table 6. The effect of disinfection on Mycocentrospora acerina in peat debris. The tests were carried out on carrots.

\begin{tabular}{|c|c|c|c|}
\hline \multirow[t]{2}{*}{ Treatment } & \multicolumn{2}{|c|}{ Spread of the disease, $\mathrm{mm}$} & \multirow{2}{*}{$\frac{\text { Efficiency \% }}{\text { Mean }}$} \\
\hline & $\begin{array}{l}\text { Trial } 1 \\
30 \mathrm{~min}\end{array}$ & $\begin{array}{l}\text { Trial } 2 \\
60 \mathrm{~min}\end{array}$ & \\
\hline Healthy control & $0 \mathrm{a}$ & $0.2 \mathrm{a}$ & \\
\hline Water & $16.5 \mathrm{c}$ & $17.8 \mathrm{~d}$ & \\
\hline Formaline & $2.4 \mathrm{ab}$ & $21.0 \mathrm{~d}$ & 32 \\
\hline Iobac P & $4.6 \mathrm{~b}$ & $11.7 \mathrm{c}$ & 53 \\
\hline Ipasept & - & $13.1 \mathrm{c}$ & - \\
\hline Menno-Ter-forte & $1.4 \mathrm{a}$ & $6.0 \mathrm{~b}$ & 79 \\
\hline $\mathrm{NaOCl}$ & $6.6 \mathrm{~b}$ & $10.3 \mathrm{c}$ & 51 \\
\hline Taloset & $7.8 \mathrm{~b}$ & - & - \\
\hline Virkon S $1 \%$ & - & $14.9 \mathrm{~d}$ & - \\
\hline Virkon S $2 \%$ & $0.3 \mathrm{a}$ & $3.8 \mathrm{ab}$ & 88 \\
\hline
\end{tabular}

F-values

$56.59 * * * \quad 53.28 * * *$

Values in columns marked with the same letter do not differ at $\mathrm{P}=0.05$.

$* * *=\mathrm{P} 0.001$

4). Lower than recommended concentrations were ineffective against $F$. culmorum and $F$. oxysporum.

Soaking of contaminated (fungus-peat suspension) plastic pots for $15 \mathrm{~min}$ in the disinfection suspension was sufficient to eradicate Botrytis cinerea and P. foveata. Formaline, Iobac P, MennoTer-forte and $\mathrm{NaOCl}$ were the most effective disinfectants against $F$. culmorum, $F$. oxysporum and Rhizoctonia solani. Ipasept, Korsolin and Sanisept were the weakest disinfectants on polyethene sur-
Table 7. The effect of disinfection on Phoma foveata in peat debris. The tests were carried out on potato tubers.

\begin{tabular}{|c|c|c|c|}
\hline \multirow[t]{2}{*}{ Treatment } & \multicolumn{2}{|c|}{ Spread of the disease, $\mathrm{mm}$} & \multirow{2}{*}{$\frac{\text { Efficiency } \%}{\text { Mean }}$} \\
\hline & $\begin{array}{l}\text { Trial } 1 \\
30 \mathrm{~min}\end{array}$ & $\begin{array}{l}\text { Trial } 2 \\
60 \mathrm{~min}\end{array}$ & \\
\hline Healthy control & $0 \mathrm{a}$ & $0 \mathrm{a}$ & \\
\hline Water & $19.2 \mathrm{~d}$ & $15.3 \mathrm{c}$ & \\
\hline Formaline & $1.9 \mathrm{ab}$ & $0.8 \mathrm{ab}$ & 92 \\
\hline Iobac P & $6.3 \mathrm{bc}$ & $1.4 \mathrm{ab}$ & 77 \\
\hline Ipasept & - & $2.8 \mathrm{~b}$ & - \\
\hline Menno-Ter-forte & $5.4 \mathrm{~b}$ & $0.3 \mathrm{a}$ & 84 \\
\hline $\mathrm{NaOCl}$ & $4.7 \mathrm{~b}$ & $0.3 \mathrm{a}$ & 86 \\
\hline Taloset & $10.0 \mathrm{c}$ & - & - \\
\hline Virkon S $1 \%$ & - & $0.7 \mathrm{ab}$ & - \\
\hline Virkon S $2 \%$ & $0.6 \mathrm{a}$ & $0.2 \mathrm{a}$ & 98 \\
\hline F-values & $58.71^{* * * *}$ & $107.44 * * *$ & \\
\hline
\end{tabular}

faces contaminated with fungus-peat mixture (Table 5).

In the trials where disinfected peat containing Mycocentrospora acerina was tested on the carrots, the most effective disinfectant was $2 \%$ Virkon S. Menno-Ter-forte had a moderate effect. The effect of other disinfectants was weak (Table 6). In the potato trial on Phoma foveata Virkon S ( $2 \%$ ) was superior in efficacy to the other disinfectants. Taloset and Ipasept were the weakest preparations (Table 7). 
Table 8. The effect of disinfection on club rot (Plasmodiophora brassicae) from contaminated plastic containers. The containers were washed with water before disinfection. Rape was used as test plant.

\begin{tabular}{|c|c|c|c|c|c|}
\hline \multirow[t]{2}{*}{ Treatment } & \multicolumn{4}{|c|}{ Disease- $\%$ of seedlings } & \multirow[t]{2}{*}{ Efficiency\% } \\
\hline & Trial 1 & Trial 2 & Trial 3 & Mean & \\
\hline No washing, control & $73.1 \mathrm{a}$ & $61.4 \mathrm{a}$ & $91.5 \mathrm{a}$ & 75.3 & \\
\hline Water, control & $5.8 \mathrm{~b}$ & $7.1 \mathrm{~b}$ & $46.2 \mathrm{~b}$ & 19.7 & 73 \\
\hline Formaline & $3.4 \mathrm{~b}$ & $0.9 \mathrm{~b}$ & $0.6 \mathrm{c}$ & 1.6 & 98 \\
\hline Iobac P & $3.2 \mathrm{~b}$ & $0.3 \mathrm{~b}$ & $0.3 \mathrm{c}$ & 1.3 & 98 \\
\hline Menno-Ter-forte & $1.1 \mathrm{~b}$ & $0 \mathrm{~b}$ & $0 \mathrm{c}$ & 0.4 & 99 \\
\hline $\mathrm{NaOCl}$ & $3.4 \mathrm{~b}$ & $2.2 \mathrm{~b}$ & $0.8 \mathrm{c}$ & 2.0 & 98 \\
\hline Taloset & - & - & $1.0 \mathrm{c}$ & 1.0 & - \\
\hline Virkon S, 2 \% & $3.3 \mathrm{~b}$ & $0.3 \mathrm{~b}$ & $0.3 \mathrm{c}$ & 1.4 & 98 \\
\hline
\end{tabular}

$\begin{array}{llll}\text { F-values } & 39.05^{* * *} & 48.78^{* * * *} & 184.52^{* * *}\end{array}$

Values in columns marked with the same letter do not differ at $\mathrm{P}=0.05$.

$* * *=\mathrm{P} 0.001$

Table 9. The effect of disinfection on Rhizoctonia solani in peat debris. Cauliflower was used as test plant.

\begin{tabular}{|c|c|c|c|c|c|}
\hline \multirow[t]{2}{*}{ Treatment } & \multicolumn{4}{|c|}{ Healthy seedlings, $\%$} & \multirow[t]{2}{*}{ Efficiency \% } \\
\hline & Trial 1 & Trial 2 & Trial 3 & Mean & \\
\hline Healthy control & $100.0 \mathrm{a}$ & 98.9 a & $98.8 \mathrm{a}$ & 99.2 & \\
\hline Water, control & $36.8 \mathrm{ab}$ & $4.0 \mathrm{~b}$ & $0 \mathrm{~b}$ & 13.6 & \\
\hline Formaline & $100.0 \mathrm{a}$ & $100.0 \mathrm{a}$ & $95.4 \mathrm{a}$ & 98.5 & 98 \\
\hline Iobac P & $31.0 \mathrm{ab}$ & $61.3 \mathrm{ab}$ & $57.0 \mathrm{ab}$ & 49.8 & 42 \\
\hline Ipasept & $5.1 \mathrm{~b}$ & $24.2 \mathrm{~b}$ & $20.2 \mathrm{~b}$ & 16.5 & 3 \\
\hline Menno-Ter-forte & $77.0 \mathrm{ab}$ & $91.5 \mathrm{a}$ & $72.4 \mathrm{ab}$ & 80.3 & 77 \\
\hline $\mathrm{NaOCl}$ & $31.5 \mathrm{ab}$ & $44.3 \mathrm{ab}$ & $41.3 \mathrm{~b}$ & 39.0 & 29 \\
\hline Taloset & $79.5 \mathrm{ab}$ & 34.4 b & $25.2 \mathrm{~b}$ & 46.4 & 38 \\
\hline Virkon S, 2 \% & $100.0 \mathrm{a}$ & $96.0 \mathrm{a}$ & $81.4 \mathrm{a}$ & 92.5 & 91 \\
\hline
\end{tabular}

$\begin{array}{llll}\text { F-values } & 3.73^{*} & 8.71^{* * *} & 7.87 * * *\end{array}$

Values in columns marked with the same letter do not differ at $\mathrm{P}=0.05$.

$*=\mathrm{P} 0.05,{ }^{* * *}=\mathrm{P} 0.001$

\section{The effect of disinfectants on club rot (Plasmodiophora brassicae)}

Washing under running water without a brush, the plastic pots were not sufficiently free from club rot. All tested disinfectants were effective against club rot, but none of them eradicated it totally. The differences between the preparations were not significant (Table 8).

\section{The effect of disinfectants on damping-off (Rhizoctonia solani)}

Formaline and Virkon S were the most effective against Rhizoctonia induced damping-off. Menno-Ter-forte also performed well. Ipasept, Iobac $\mathrm{P}$ and $\mathrm{NaOCl}$ were the weakest disinfectants (Table 9). 


\section{Discussion}

In the present trials, $100 \%$ effect against Fusarium oxysporum mixed in peat was achieved only with $\mathrm{NaOCl}(10 \%)$ after $100 \mathrm{~min}$ exposure time. These results are opposite to those of BÖHMER (1983) who showed that $\mathrm{NaOCl}(1 \%)$ had no effect on F.oxysporum. This is due to the higher concentration of $\mathrm{NaOCl}$ used in the present study. Menno-Ter-forte, Virkon S and formaline were also effective against the fungus in a small amount of peat $(0.1 \mathrm{~g} / 11 \mathrm{l}$ disinfectant). Also BÖHMER (1985) showed that a small amount of peat $(15-30 \mathrm{~g} / \mathrm{l})$ does not decrease the effect of Menno-Ter-forte on F. oxysporum but a large amount $(60 \mathrm{~g} / \mathrm{l})$ decreases the effect of Menno-Ter-forte. Under clean conditions MennoTer-forte $(0.5 \%)$ has been shown to inhibit the growth of $F$. oxysporum conidia even after 5 and 10 min treatment time (BÖHMER 1983, BRIELMAIER 1985) but this and other studies (BÖHMER 1985) confirm that the peat in the disinfection solution decreases the effect of Menno-Ter-forte and a treatment time of $60 \mathrm{~min}$ at least should be used. According to BAANDRUP (1983), 2 \% Korsolin inhibited the growth of $F$. oxysporum, but we used $1 \%$ Korsolin and it was too weak against $F$. oxysporum. In this study, Iobac P did not inhibit totally the growth of $F$. oxysporum and the effect of Iobac $\mathrm{P}$ was decreased in the presence of peat.

$\mathrm{NaOCl}$ was the most effective against $F$. culmorum mixed in peat after 10 min treatment time. Menno-Ter-forte was moderately effective against $F$. culmorum mixed in peat when used at the recommended concentration. BRIELMAIER (1985), too, showed that Menno-Ter-forte prevents the germination of conidia of $F$. culmorum under clean conditions. When using a treatment time of 100 min, only Korsolin was ineffective against $F$. culmorum. Also this study showed that a treatment time of at least $60 \mathrm{~min}$ should be used.

According to BÅNG (1987a, b), formaline is effective against Phoma foveata and $F$. solani, but Iobac $\mathrm{P}$ is not. In the present trials, Iobac $\mathrm{P}$ was a weak disinfectant against $P$. foveata mixed in peat, but formaline was effective against $P$. foveata.

In this and other studies (SUNDHEIM 1991), formaline was effective against Rhizoctonia solani mixed in peat after a treatment of $60 \mathrm{~min}$. Also Virkon $\mathrm{S}$ was effective against the fungus and it was equal to formaline in disinfecting $R$. solani from peat but in disinfecting plastic pots Virkon $\mathrm{S}$ was ineffective against $R$. solani. In the present trials, Iobac $\mathrm{P}$ was very effective against $R$. solani in disinfecting plastic pots, but in disinfecting $R$. solani from peat it performed poorly. The results are partly affected by the fact that Iobac P caused damage to the cauliflower seedlings, which were used as test plants. Damping-off of cauliflower could not always be distinguished from the phytotoxicity injuries caused by Iobac P. The use of cauliflower to indicate the efficacy of disinfectants is not the best choice because many disinfectants in peat cause phytotoxicity injuries to plants (AVIKAINEN et al. 1993).

$F$. oxysporum was effectively eradicated from plastic pots with formaline, Iobac P, Menno-Terforte, Ipasept and $\mathrm{NaOCl}$. Fifteen minutes exposure time was enough for formaline and Menno-Terforte, but Iobac P, Ipasept and $\mathrm{NaOCl}$ needed 60 min. In these trials, Korsolin and Virkon $\mathrm{S}$ were effective against $F$. oxysporum although the effect was not perfect.

In the present study, all the tested disinfectants were effective against Botrytis cinerea when plastic pot surfaces were contaminated with a fungus and peat mixture. A treatment time of 15 min was sufficient for all disinfectants except Korsolin. In this and other studies, formaline was effective against $B$. cinerea (Hortica 1985, JoHANSSON 1985, SUNDHEIM 1989, 1991). Menno-Ter-forte has proved effective against grey mold growing on pieces of paper or on synthetic cloth, but not on pieces of wood (SUNDHEIM 1991, KOPONEN et al. 1992b). According to SUNDHEIM (1991), Virkon S (1\%) is not effective against grey mold, but this study showed that it is a very good compound in disinfecting plastic pots contaminated with fungus and peat.

In disinfecting plastic pots all disinfectants were effective against $P$. foveata after a treatment of 60 min. According to BÅNG (1987a, b), formaline is effective against $P$. foveata. The result is in accordance with this study.

In greenhouse trials imitating seedling production, 60 min treatment of plastic pots in disinfection 
suspension against Plasmodiophora brassicae gave a good result although none of the disinfectants were capable of eradicating the fungus totally. Also in other studies Menno-Ter-forte $(1.5 \%)$ has been effective against $P$. brassicae when plastic pots were soaked in disinfection solution for $12 \mathrm{~h}$ (HADLER 1988). Whereas only washing with water or spraying of the disinfectant on the surface to be disinfested was not sufficient to eradicate club rot (HADLER 1988).

The present trials confirm the fact that dirt and organic material decrease the effect of disinfectants. The dirtier the surface to be cleaned, the longer disinfection time is needed. The disinfection time should always be at least $60 \mathrm{~min}$. Although $15 \mathrm{~min}$ or less is sufficient in laboratory tests to eradicate the pathogen, it is not necessarily sufficient in practice.

Virkon $\mathrm{S}$, Iobac $\mathrm{P}$ and $\mathrm{NaOCl}$ are effective disinfectants against many potato pathogens, e.g. Rhizoctonia solani, Phoma foveata and Fusarium spp. Iobac $\mathrm{P}$ can be used also for bacterial ring rot of potato (Clavibacter michiganensis subsp. sepedonicus) and black leg (Erwinia carotovora subsp. atroseptica) (KOPONEN et al. 1992a).

Iobac P, Menno-Ter-forte and Virkon S are good alternatives to those who want to avoid formaline in disinfection of plastic pots from Plasmodiophora brassicae.

Formaline and Virkon $\mathrm{S}$ are effective against $R$. solani when organic material is present, but plastic surfaces may be disinfected with Iobac P, MennoTer-forte, $\mathrm{NaOCl}$ and formaline.

\section{References}

Avikainen, H., Koponen, H., Meinander, B. \& Tahvonen, R. 1993. The phytotoxicity of disinfectants and their effect at different temperatures. Agric. Sci. Finl. 2:

BAANDRUP, M. 1983. Desinfektionsmidler. Specialrapport vid Köpenhamns universitet (Ref. Johansson 1985).

BẢNG, U. 1987a. Försök med desinfektionsmedel. Spor potatisodl. 5 (2): 32-34

- 1987b. Redovisning av försök med desinfektioin genom dimning i konstantrum vid Röbäcksdalen i september 1986. Mimeogr. 5 p.

BÖHMER, B. 1983. Untersuchungen zum Einsatz von Desinfektionsmitteln im Zierpflanzenbau. Gesunde Pfl. 35: 189-197.

— 1985. Nicht alle Mittel wirken unter Schmutzbelastung. Gärtnerbör. und Gartenw. 85: 836-838.

Bоoтн, C. 1971. Methods in microbiology. Academic Press. London. Vol. 4. 795 p.

BRIEL.MAIER, U. 1985. Wirkung von Desinfektionsmitteln auf pilzliche Krankheitserreger, die im Zierpflanzenbau von Bedeutung sind. Meded. Fac. Landbouww. Rijksuniv. Gent 50/3b: 1235-1242.

DenNIS, C. 1983. Post-harvest pathology of fruits and vegetables. Academic Press. London. 264 p.

Domsch, K. H., Gams, W. \& Anderson, T.-H. 1980. Compendium of soil fungi. Academic Press. London. Vol. 1. 859 p.

Hadler, C. 1988. Versuchbericht zur Prüfung der Eignung von Menno-Ter-forte zur Desinfektion von Jungpflanzenanzuchtgefässen. Mimeogr. 2 p.

HeINZE, K. 1974. Leitfaden der Schädlingsbekämpfung.
Band 1. Schädlinge und Krankheiten im Gemüsebau. Wissenschaftliche Verlagsgesellschaft MBH. Stuttgart. $360 \mathrm{p}$.

Hortica 1985. Kan formalin ersättäs? Hortica 2 (9): 23-25

JoHANSSON, A.-K. 1985. Löpande desinfektion i växthus av Xanthomonas pelargonii och $X$. begoniae. Disinfektion in greenhouses of Xanthomonas pelargonii and X. begoniae. Institutionen för växt- och skogsskydd. (Sveriges Lantbr. Univ.) Examensarbeten 1985 (5) Uppsala. 67 p.

Ko, W.-H. \& HoRA, F. K., 1971. A selective medium for quantitative determination of Rhizoctonia solani in soil. Phytopathology 61: 707-710.

Koponen, H., Manninen, M., Harju, P., Avikainen, H. \& Tahvonen, R. 1992a. The effect of disinfectants on Clavibacter michiganensis subsp. sepedonicus and Erwinia carotovora subsp. atroseptica on different surface materials. Agric. Sci. Finl.1: 597-602.

Koponen, Avikainen, H. \& Tahvonen, R. 1992b. The effect of disinfectants on fungi in pure culture and on different surface materials. Agric. Sci. Finl. 1: 587-596.

SEPPÄNEN, E. 1983. Fusariums of the potato in Finland VIII. Occurence of the pathogens causing potato dry rot and gangrene. Ann. Agric. Fenn. 22: 115-119.

SundHeIM, L. 1989. Desinfeksjonsmiddel mot soppar. Akt. Stat. Fagtj. Landbr. 3: 89-95.

- 1991. Reingering og desinfeksjon mot sjukdomar i veksthus. Plantevern i veksthus. Etterutdanninngskurs arrangert av statens fagtjeneste for landbruket 1991. Mimeogr. 5 p. 
Manuscript received July 1992

Hilkka Koponen

Department of Plant Biology

P.O.Box 28

FIN-00014 University of Helsinki, Finland
Hanna Avikainen

Risto Tahvonen

Agricultural Research Centre of Finland

Institute of Plant Protection

FIN-31600 Jokioinen, Finland

\title{
SELOSTUS
}

\section{Desinfiointiaineiden teho perunan ja vihannesten sienitauteihin}

\author{
HilkKa Koponen, Hanna Avikainen ja Risto TAHVonen
}

Helsingin yliopisto ja Maatalouden tutkimuskeskus

Yhdeksän markkinoilla olevan desinfiointiaineen tehoa vihannesten ja perunan tauteja aiheuttaviin sieniin tutkittiin Kasvinsuojelun tutkimuslaitoksella vuosina 1988-1990. Tutkittavat valmisteet olivat formaliini (formaldehydi), Iobac P (jodi), Ipasept, Menno-Ter-forte ja Sanisept ja Taloset (kvartaarisia ammoniumyhdisteitä), Korsolin (glutaraldehydi), natriumhypokloriitti (aktiivinen kloori) ja Virkon S (kaliumperoksisulfaatti).

Laboratoriotesteissä tutkittiin valmisteiden suositeltujen käyttöväkevyyksien tehoa turpeessa tai kasvijätteessä oleviin Bortrytis cinerea-, Fusarium culmorum-, Fusarium oxysporum-, Mycocentrospora acerina- ja Phoma foveata- sieniin. Lisäksi testattiin käsitelyajan vaikutusta valmisteiden tehoon. Sienten elävyys testattiin agarmaljoilla. Porkkananmustamätä $(M$. acerina $)$ ja perunan Phoma-mätä $(P$. foveata $)$ testattiin laittamalla saastutettu ja desinfioitu turve porkkanoihin ja perunoihin ja säilyttämällä juureksia varasto-olosuhteissa. Turve- ja kasvijätteessä olevien taudinaiheuttajien desinfiointia muovipinnalta tutkittiin liottamalla liattuja muoviruukun paloja eri aikoja desinfiointiaineissa. Sienten elävyys testattiin agarmaljoilla.

Yhden ja kymmenen minuutin vaikutusajat olivat kaikilla valmisteilla liian lyhyitä turpeessa ja kasvijätteissä oleviin sieniin. Paras teho saatiin 1,5 tunnin käsittelyllä. F. culmorum- ja $F$. oxysporum- sieniin paras teho oli natriumhypokloriitilla, huonoin Korsolinilla ja Virkon S:Ilä. M. acerina- sieneen tehosi parhaiten Virkon S ( $2 \%)$. Formaliini, natriumhypokloriitti, Iobac $\mathrm{P}$ ja Taloset olivat teholtaan huonoja. Virkon $\mathrm{S}(2 \%)$ tehosi parhaiten myös $P$. foveata- sieneen.
Viidentoista minuutin ja tunnin liotus desinfiointiaineliuoksessa puhdisti liatut muoviruukut hyvin $B$. cinerea- ja $P$. foveata- sienistä. Fusarium spp.-sienet olivat vaikeimpia puhdistaa. Paras teho niihin oli Formaliini-, Iobac P-, Menno-Terforte- ja natriumhypokloriitti- valmisteilla. Korsolin, Ipasept ja Sanisept olivat teholtaan huonoja valmisteita.

Desinfioinnin vaikutusta möhöjuureen (Plasmodiophora brassicae) ja Rhizoctonia solani- taimipoltteeseen testattiin kasvihuoneessa taimikasvatuskokeissa. Möhöjuurella liattuja muovisia lokerikkoja liotettiin desinfiointiainelaimennoksissa yhden tunnin ajan. Lokerikoissa kasvatettiin rypsin taimia noin kuusi viikkoa. Taimista analysoitiin juurten tautisuus. Rhizoctonia solani taimipolte kokeessa testikasvina oli kukkakaali. Kaikki tutkitut desinfiointiaineet tehosivat hyvin möhöjuureen. Huuhtelu juoksevalla vedellä ei riittänyt möhöjuuren puhdistamiseen. Kukkakaalin Rhizoctonia-taimipoltteeseen tehosivat parhaiten formaliini ja Virkon S. Huonoimpia valmisteita olivat Ipasept, Iobac $\mathrm{P}$ ja natriumhypokloriitti.

Desinfiointiaika tulisi olla vähintään tunti. Vaikka viisitoista minuuttia ja lyhyempikin aika riitti joidenkin taudinaiheuttajien puhdistamiseen laboratoriokokeissa, se ei välttämättä riitä käytännön olosuhteissa.

Porkkanavarastojen desinfiointiin soveltuvat parhaiten Virkon S (2\%) ja Menno-Ter-forte, perunavarastojen Iobac P, Virkon $\mathrm{S}$ ja $\mathrm{NaOCl}$. Möhöjuuren desinfiointiin soveltuvat hyvin Iobac P, Menno-Ter-forte, Virkon S ja formaliini. Rhizoctonia-taimipoltteen saa parhaiten puhdistettua formaliinija Virkon S-valmisteilla. 